\title{
SISTEM PENYELEKSI WARNA DAN BERAT BARANG MENGGUNAKAN PERGERAKAN LENGAN ROBOT EMPAT DOF (DEGREE OF FREEDOM)
}

\author{
Abdullah \\ Program Studi Teknik Informatika, STTP Politeknik Poliprofesi \\ JL. Sei Batang Hari, No. 3 \& 4, Sei Sikambing B, Medan Sunggal, Kota Medan \\ abdullah2187@gmail.com
}

\begin{abstract}
The use of robot arm in the system of colour and weight box selection has been done to integrate control system of robot arm moving with colour sensor TCS3200 and weight sensor load cell. The research was conducted by analyzing efficiency and accuracy system of robot arm moving to select colour and weight goods like box. The robot arm moving work suitable instruction of colour and weight sensor reading. At the most important from this system is how to accuracy of colour and weight sensor to detect colour ang weight and accuracy of robot arm moving system can positioning degree moving to take colour with different weight box suitable the place. The result of the analysis proved that robot arm moving had inregrated with colour and weight sensor efficient and effective to do this work as colour and weight box selection accurately.
\end{abstract}

Keywords: TCS3200, Loadcell, robot arm, control system

\begin{abstract}
Abstrak
Penggunaan gerak lengan robot pada sistem penyeleksian warna dan berat barang (kotak) telah dilakukan untuk mengintegrasikan sistem kontrol gerak lengan robot dengan sensor warna TCS3200 dan sensor berat load cell. Penelitian dilakukan dengan menganalisa keefisienan dan keakuratan sistem pergerakan lengan robot dalam menyeleksi warna dan berat barang yang berupa kotak. Dimana pergerakan lengan robot ini bekerja sesuai instruksi pembacaan dari sensor warna dan sensor berat. Pada sistem ini, yang paling ditunjukkan yaitu bagaimana keakuratan sensor warna dan berat dalam mendeteksi warna dan berat serta keakuratan sistem pergerakan lengan robot yang dapat memposisikan derajat geraknya untuk meletakkan kotak berwarna dengan berat berbeda sesuai dengan wadahnya. Hasil pengujian membuktikan bahwa sistem pergerakan lengan robot yang telah diintegrasikan dengan sensor warna dan berat efisien dan efektif dalam melakukan kerjanya sebagai penyeleksi warna dan berat barang dengan akurat.
\end{abstract}

Kata kunci: TCS3200, loadcell, lengan robot, sistem kontrol

\section{PENDAHULUAN}

Perkembangan dalam teknologi robotika telah berkembang dengan pesat. Teknologi robotika juga telah banyak digunakan di negara-negara maju di dunia, 
baik sebagai pendukung kerja di industri, dirumah tangga atau pendukung kerja lainnya.

Seiring dengan perkembangan dibidang teknologi robotik, banyak penelitian yang telah dilakukan. Salah satunya masalah gerak pada robot, baik gerak jalan robot menggunakan roda, gerak jalan robot menggunakan kaki maupun masalah gerak pada lengan robot. Pada penelitian ini, penulis melakukan penelitian terhadap sistem gerak lengan robot yang diaplikasikan pada penyeleksian warna barang dan berat barang. Dimana sistem pada lengan robot ini memiliki keunggulan dibandingkan sistem pergerakan lain dalam hal penyeleksian warna dan berat, karena pergerakan lengan robot ini merupakan dasar dari sistem pergerakan pada robot humanoid.

Teknologi sistem pergerakan robot ini mempunyai banyak aplikasi, terutama dalam dunia industri, memproduksi barang tidak lagi dalam jumlah yang sedikit sehingga waktu kerja juga menjadi tidak terbatas, belum lagi masalah keakuratan dalam kerja menjadi hal yang sangat penting dan tidak semua proses produksi tersebut dapat dilakukan oleh tenaga manusia yang masih mempunyai batas kemampuan dan jika tetap dipaksakan pada akhrirnya jumlah produksi barang berkurang serta efisien waktu tidak tercapai. Manusia juga dapat rentan dalam melakukan kesalahan seperti pada proses penyeleksian barang. Pada sistem pergerakan lengan robot dalam menyeleksi warna dan berat ini menggunakan ATMega 32 sebagai pusat pengolahan data dengan mengintegrasikan gerak lengan robot dengan sensor warna dan sensor berat.

\section{LANDASAN TEORI}

\subsection{Teknik Desain Robot}

Menurut Robot Institute of America, salah satu riset unggulan di Carnigie Mellon University, robot merupakan suatu sistem yang dapat di program dan dapat diprogram kembali, memiliki komponen-komponen, dirancang dengan sistem manipulator mekanik agar dapat melakukan pemindahan barang-barang dengan suatu program yang diisikan dan disesuaikan untuk dapat melaksanakan berbagai macam tugas [1]. Sehingga robot dapat diartikan sebagai suatu sistem automatis yang dapat di program (Programmable Automation). Pada teknik desain robot terdapat struktur bagian-bagian penting yang diperlukan untuk merancang robot, yaitu sistem kontroler, mekanik robot, sensor dan aktuator [2].

\subsection{Sistem Mekanik Robot}

Mekanik robot merupakan sistem bentuk desain mekanik yang berfungsi sebagai suatu sistem gerak pada robot. Sistem gerak tersebut disebut dengan Degree Of Freedom (DOF) atau sering di artikan dengan sendi. Setiap robot setidaknya memiliki sistem gerak berupa satu sendi. Sebuah sendi digerakkan oleh sebuah actuator. Mekanik pada suatu robot juga digunakan sebagai chasis atau pondasi sebuah sistem robot, agar robot dapat bergerak dengan baik [2].

\subsection{Sistem Kontrol Robot}

Sistem kontrol merupakan bagian yang sangat paling utama dan paling berperan dalam sistem robotik. Tanpa adanya sistem kontrol, sistem robotik itu hanya akan 
menjadi benda mati (sistem robot tersebut tidak dapat berfungsi). Sistem kontrol pada robot terdiri dari dua bagian utama, yaitu perangkat keras (hardware) dan perangkat lunak (software), yaitu metode algoritma kontrol [2].

Secara garis besar, suatu sistem robotik terdiri dari tiga bagian utama seperti yang di perlihatkan dalam Gambar 1 dibawah ini :

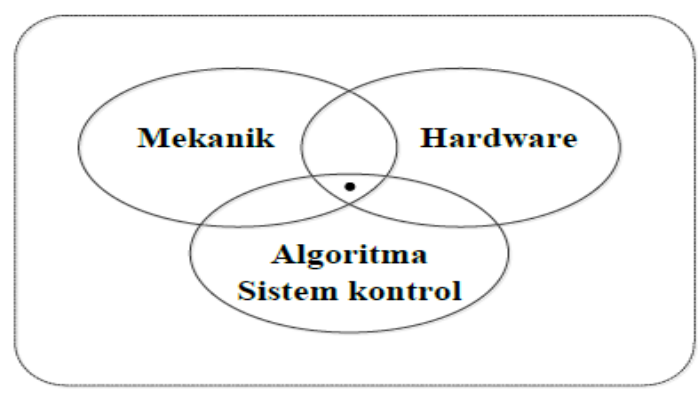

Gambar 1. Sistem Robotik

Pada Gambar 1 algoritma sistem kontrol merupakan bagian yang tidak dapat terpisahkan dalam suatu sistem robotik. Sistem kontrol berfungsi untuk menggabungkan/menghubungkan sistem perangkat keras elektronik dan desain mekanik dengan baik sehingga mencapai suatu fungsi seperti yang diinginkan. Tanda titik (.) yang terdapat pada interseksi sistem robotik, menandakan bahwa ketiga bagian dari sistem robotik, baik sistem mekanik, hardware dan algoritma sistem kontrol merupakan bagian yang tidak dapat di pisahkan dalam membuat suatu sistem robotika [3][4].

\subsection{Sensor}

Untuk mengendalikan sebuah pergerakan lengan yang dapat menyeleksi warna barang dengan akurat, maka robot tersebut harus dilengkapi beberapa sensor yang di tujukan sebagai informasi data yang selanjutnya akan diolah oleh kontroler agar robot tersebut dapat melakukan tugasnya sesuai yang diinginkan. Terdapat beberapa jenis sensor yang di gunakan, yaitu sensor warna TCS3200 dan sensor berat loadcell serta sensor fotodioda infra merah. [4][5][6][7][8].

\subsection{Actuator}

Actuator merupakan bagian dari sistem mekanik atau peralatan mekanik yang berfungsi untuk sistem pergerakan atau pengontrolan pada sebuah mekanisme suatu sistem. Actuator difungsikan pada lengan mekanik yang digerakkan oleh motor servo, yang dikontrolkan melalui sistem pengontrol otomatis secara terprogram seperti pada mikrokontroler atau sistem tertanam lainnya. Dari actuator inilah robot dapat melakukan gerakan sesuai dengan pengontrolan yg telah diberikan (diprogram). Jenis actuator yang digunakan pada robot yaitu actuator jenis motor servo [2].

\subsection{Sistem tertanam pada robot}

Embedded system atau sistem tertanam merupakan sistem berbasis komputer (computer-based) yang di program untuk tugas tertentu dan ditanamkan sebagai suatu bagian didalam sistem komputer atau didalam suatu peralatan dan 
kadang-kadang tidak menampakkan bahwa peralatan itu dikendalikan oleh komputer. Prosesor atau controler yang paling banyak digunakan dalam embedded system adalah mikrokontroler, berupa chip. Pada penelitian ini digunakan mikrokontroler ATmega 32 dari rumpun AVR [9][10][11].

\section{METODELOGI PENELITIAN}

Secara umum metode yang digunakan dalam penelitian ini terdiri dari perancangan perangkat keras dan perancangan perangkat lunak pada sistem penyeleksi warna dan berat barang menggunakan pergerakan lengan robot 4 (empat) DoF.

\subsection{Perancangan Perangkat Keras (hardware)}

Perancangan perangkat keras terdiri atas dua bagian utama, yaitu perancangan sistem mekanik dan perancangan sistem elektrik. Pada perancangan mekanik terdiri atas bentuk/desain fisik robot, sedangkan perancangan elektrik terdiri dari perancangan sistem rangkaian elektrik, sensor, dan motor penggerak. Gambar 2 menunjukkan perancangan mekanik lengan robot empat DoF yang akan dirancang dan Gambar 3 menunjukkan diagram blok untuk desain perangkat keras (hardware) secara keseluruhan.
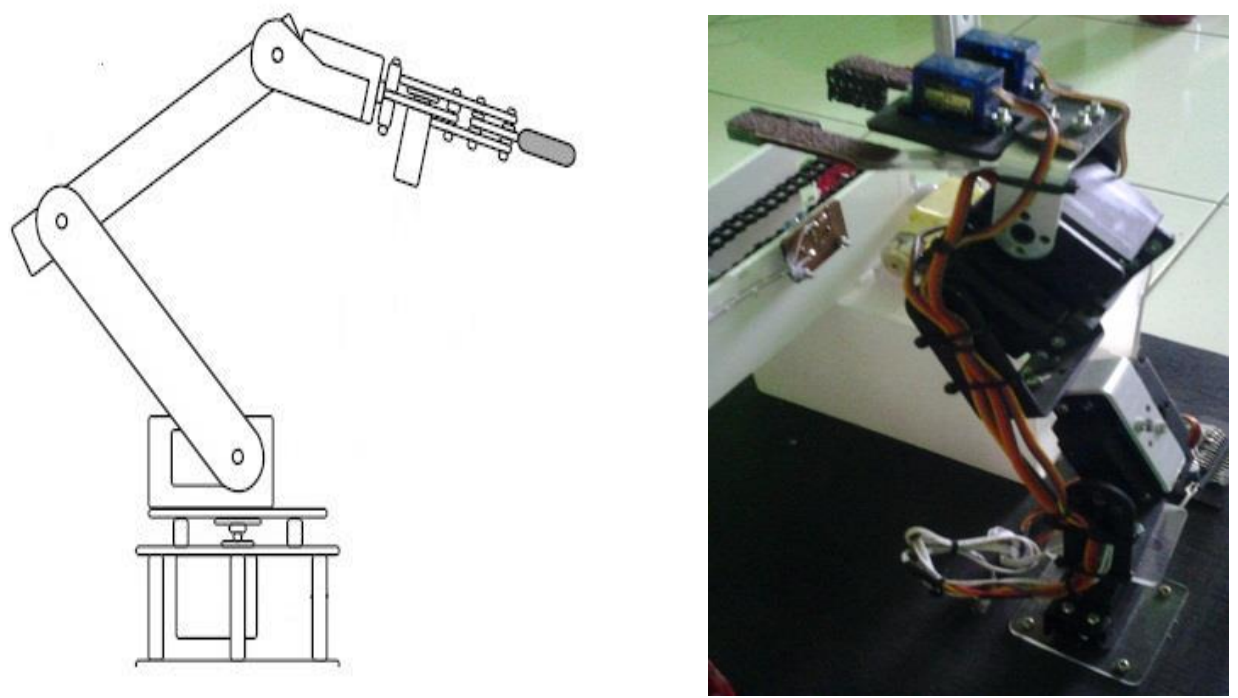

Gambar 2. Perancangan mekanik lengan robot

Pada perancangan mekanik diatas bahan-bahan yang digunakan, yaitu servo bracket berbagai bentuk sebagai penghubung mekanik antar servo. Untuk bahan mekanik lain menggunakan bahan acrylic, dikarenakan bahan ini kuat, mudah dibentuk. 


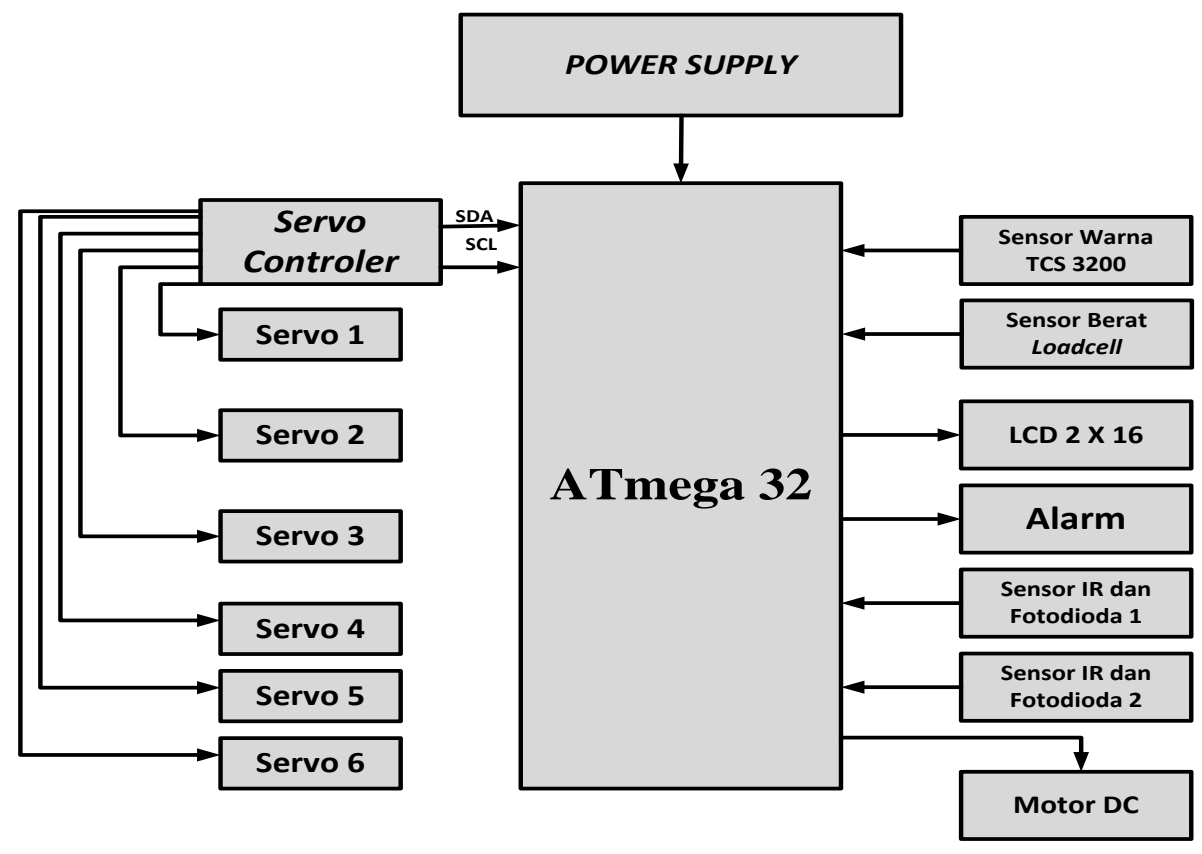

Gambar 3. Diagram blok perangkat keras (hardware) secara keseluruhan berikut :

Fungsi kerja masing-masing blok perangkat keras (hardware) diatas sebagai

a. Satu buah mikrokontroler (Chip Programmable) yang terdiri dari mikrokontroler seri ATmega32, difungsikan sebagai pusat pengendalian, baik data input sensor maupun output. Data input tersebut didapat dari 3 buah sensor, yaitu sensor warna, berat, dan sensor halangan. Dari pembacaan ketiga sensor itu yang sudah masuk ke mikrokontroller, maka mikrokontroller akan mengendalikan seluruh output sesuai kerja yang diinginkan, seperti tampilan pesan di LCD 2x16, alarm, motor DC serta kombinasi variasi gerak servo sesuai yang ditentukan.

b. Satu buah sensor warna dengan tipe TCS3200.

Sensor warna ini difungsikan sebagai pendeteksi warna setiap barang. Pembacaan sensor warna ini masih dalam keadaan analog, sehingga harus diproses terlebih dahulu menggunakan ADC internal mikrokontroller sehingga mendapatkan data digital agar mudah diproses.

c. Satu buah sensor berat loadcell

Sensor berat ini difungsikan sebagai pendeteksi berat setiap barang. Pembacaan sensor berat ini masih dalam keadaan analog, sehingga harus diproses terlebih dahulu menggunakan ADC internal mikrokontroller sehingga mendapatkan data digital agar mudah diproses.

d. Dua buah sensor halangan (fotodioda-inframerah)

Sensor halangan ini difungsikan sebagai pendeteksi barang yang melewati conveyor, tujuannya agar barang tersebut dapat diberhentikan sejenak agar sensor warna dan barang dapat bekerja dengan baik dan sebagai pemberhentian sehingga lengan robot dapat mengambil barang dengan akurat. Sensor halangan ini diproses menggunakan rangkaian komparator sehingga data yang dihasilkan 
sudah merupakan data digital. Sehingga dapat langsung diproses oleh mikrokontroller tanpa harus melalui proses pengolahan ADC.

e. Satu buah relay controller

Relay controller difungsikan untuk mengendali hidup atau matinya alarm yang ada pada sistem.

f. Satu buah adaptor 12 Volt $3000 \mathrm{mAh}$.

Adaptor $3000 \mathrm{mAh}$ difungsikan untuk penyuplay tegangan dan arus pada seluruh sistem elektronika yang digunakan, agar sistem dapat bekerja dengan baik.

g. Satu buah regulator 5 Volt.

Regulator 5 Volt difungsikan untuk memenuhi kebutuhan supply rangkaian elektronika yang membutuhkan tegangan 5 Volt. Sehingga dengan regulator ini supplay awal yang bernilai 12 Volt dapat diturunkan menjadi 5 Volt.

h. Enam buah motor servo.

Motor servo difungsikan untuk mengerakkan variasi lengan robot agar dapat bekerja sesuai gerakan yang diinginkan dalam mengambil barang.

i. Satu buah motor dc

Motor dc difungsikan untuk menggerakan putar conveyor yang membawa barang menuju sistem penyeleksian warna dan beratnya.

j. Satu buah servo controller dengan tipe SPC Servo Controller

Servo controller difungsikan sebagai pengendali seluruh servo yang digunakan, misalnya pergerakan seberapa besar derajat kerja dari masing-masing servo dan seberapa cepat pergerakan servo dalam melakukan gerakan.

k. Satu buah LCD $2 \times 16$.

LCD $2 \times 16$ difungsi sebagai tampilan dari kerja sistem yang berbentuk tulisan karakter, misalnya warna yang terdeteksi, berapa nilai berat yang terbaca sensor.

\subsection{Perancangan perangkat lunak}

Perancangan perangkat lunak (software) menggunakan pemrograman bahasa C dengan software Code Vision AVR sebagai software utama untuk pemrograman pada sistem penyeleksi warna dan berat dengan lengan robot dan software downloader ProgIsp programmer merupakan software untuk download program utama robot ke mikrokontroler. Tampilan software dalapat dilihat di gambar 4 Keseluruhan perangkat lunak akan menyesuaikan dengan perangkat keras yang telah dirancang pada robot.
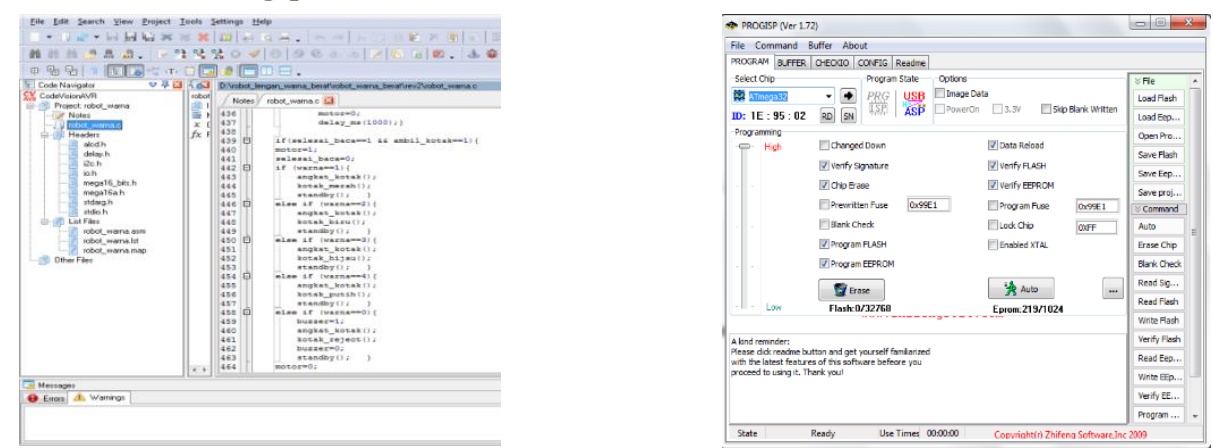

Gambar 4. Tampilan software Code Vision AVR dan software ProgIsp programmer 


\section{HASIL DAN PEMBAHASAN}

Hasil yang dibahas pada penelitian ini adalah pengujian keakuratan lengan robot dalam meletakkan setiap barang (kotak) berwarna dengan berat berbedabeda ke wadahnya masing-masing. Di penelitian ini wadah warna dan berat dibagi atas 5 kelompok wadah warna dengan 5 variasi berat, yaitu variasi warna merah adalah wadah merah dengan berat 10 gr, wadah merah dengan berat 20 gr, wadah merah dengan berat $30 \mathrm{gr}$, wadah merah dengan berat $40 \mathrm{gr}$, wadah merah dengan berat 50 gr. Variasi warna biru adalah wadah biru dengan berat $10 \mathrm{gr}$, wadah biru dengan berat $20 \mathrm{gr}$, wadah biru dengan berat $30 \mathrm{gr}$, wadah biru dengan berat $40 \mathrm{gr}$, wadah biru dengan berat 50 gr. Variasi warna hijau adalah wadah hijau dengan berat 10 gr, wadah hijau dengan berat 20 gr, wadah hijau dengan berat 30 gr, wadah hijau dengan berat 40 gr, wadah hijau dengan berat 50 gr. Variasi warna putih adalah wadah putih dengan berat $10 \mathrm{gr}$, wadah putih dengan berat 20 gr, wadah putih dengan berat $30 \mathrm{gr}$, wadah putih dengan berat $40 \mathrm{gr}$, wadah putih dengan berat 50 gr. Serta terdapatnya wadah reject yang juga divariasikan dalam bergai variasi berat. Dari seluruh wadah tersebut lengan robot yang dirancang harus dapat memasukkan kotak berwarna dengan berat berbeda ke dalam kelompok wadah yang telah ditentukan. Misalkan disaat lengan robot mengambil kotak berwarna merah dengan berat $10 \mathrm{gr}$ maka lengan robot tersebut harus dapat memposisikan derajat geraknya ke wadah merah dengan berat $10 \mathrm{gr}$, begitu juga dengan wadah yang lainnya. Wadah reject yang dimaksud yaitu wadah tempat peletakan warna dan berat selain warna merah, biru, hijau dan putih dengan masing-masing berat (jika salah satu warna atau berat tidak terdefinisi kelompok yang diinginkan, berarti kategorinya adalah reject). Misalkan saja kotak berwarna hitam, abu-abu harus termasuk kedalam kotak reject. Hasil desain robot yang telah dirancang dapat dilihat pada Gambar 5.

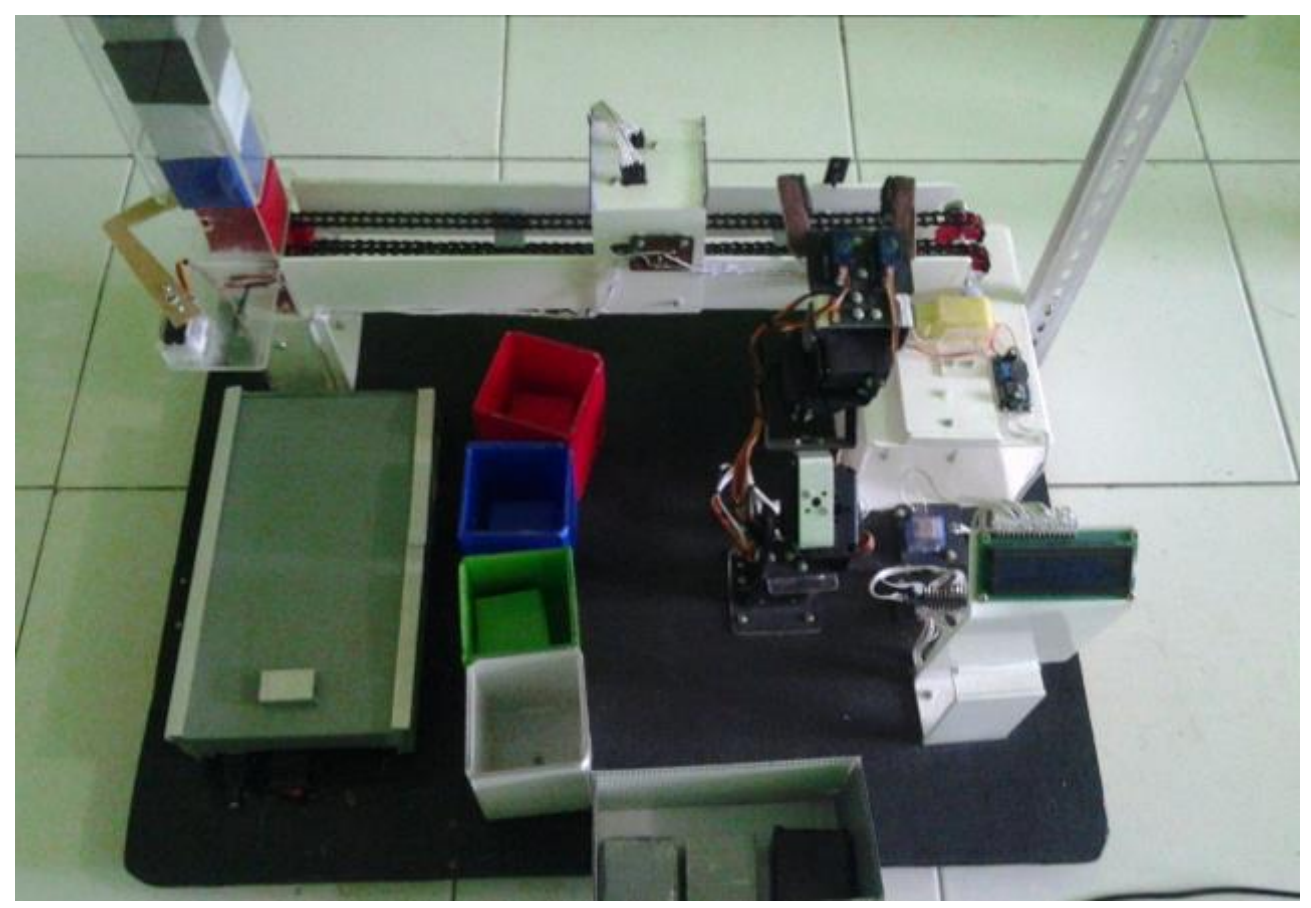

Gambar 5. Hasil rancangan sistem secara keseluruhan serta tampilan LCD 
Hasil pengujian dari sampel beberapa warna dan berat yang dilakukan dapat dilihat pada Tabel 1, Tabel 2, Tabel 3, Tabel 4, Tabel 5, Tabel 6.

Tabel 1 Hasil Pengujian Keakuratan Gerak Lengan Robot dalam Menyeleksi warna

\begin{tabular}{|c|c|c|c|c|c|c|c|}
\hline \multirow[t]{2}{*}{ No. } & \multirow[t]{2}{*}{$\begin{array}{c}\text { Kotak } \\
\text { Berwarna }\end{array}$} & \multicolumn{3}{|c|}{$\begin{array}{c}\text { Nilai data keluaran } \\
\text { sensor warna }\end{array}$} & \multirow[t]{2}{*}{$\begin{array}{l}\text { Tampilan } \\
\text { LCD }\end{array}$} & \multirow[t]{2}{*}{$\begin{array}{l}\text { Pergerakan } \\
\text { lengan robot }\end{array}$} & \multirow[t]{2}{*}{ Kesimpulan } \\
\hline & & Red & Green & Blue & & & \\
\hline 1 & Merah & 6 & 1 & 2 & merah & $\begin{array}{c}\text { Menuju wadah } \\
\text { merah }\end{array}$ & Berhasil \\
\hline 2 & Biru & 1 & 2 & 6 & biru & $\begin{array}{c}\text { Menuju wadah } \\
\text { biru }\end{array}$ & Berhasil \\
\hline 3 & Hijau & 4 & 5 & 3 & hijau & $\begin{array}{c}\text { Menuju wadah } \\
\text { hijau }\end{array}$ & Berhasil \\
\hline 4 & Putih & 8 & 9 & 12 & putih & $\begin{array}{l}\text { Menuju wadah } \\
\text { putih }\end{array}$ & Berhasil \\
\hline 5 & Hitam & 0 & 0 & 1 & hitam & $\begin{array}{l}\text { Menuju wadah } \\
\text { reject }\end{array}$ & Berhasil \\
\hline 6 & Abu-abu & 4 & 4 & 5 & abu-abu & $\begin{array}{l}\text { Menuju wadah } \\
\text { reject }\end{array}$ & Berhasil \\
\hline
\end{tabular}

Keterangan :

Wadah reject yang dimaksud yaitu wadah tempat peletakan warna selain warna merah, biru, hijau dan putih. Dari tabel 1 diatas dapat dilihat bahwa sistem lengan robot yang diimplementasikan sebagai penyeleksi warna barang yang sudah diintegrasikan dengan sensor warna bekerja dengan akurat tanpa ada kesalahan dalam melakukan kerjanya.

Tabel 2 Hasil Pengujian Keakuratan Gerak Lengan Robot dalam Menyeleksi warna merah dan variasi berat barang yang sesuai (diterima)

\begin{tabular}{|c|c|c|c|c|c|}
\hline \multirow[t]{2}{*}{ No. } & \multicolumn{2}{|c|}{ Kotak } & \multirow[t]{2}{*}{ Tampilan LCD } & \multirow{2}{*}{$\begin{array}{c}\text { Pergerakan lengan } \\
\text { robot }\end{array}$} & \multirow{2}{*}{$\begin{array}{c}\text { Kesimpula } \\
\text { n }\end{array}$} \\
\hline & Warna & Berat & & & \\
\hline \multirow[t]{5}{*}{1} & \multirow[t]{5}{*}{ Merah } & $10 \mathrm{gr}$ & $\begin{array}{l}\text { merah (baris } 1) \\
10 \mathrm{gr} \text { (baris 2) }\end{array}$ & $\begin{array}{c}\text { Menuju wadah merah, } \\
\text { berat } 10 \mathrm{gr}\end{array}$ & Berhasil \\
\hline & & $20 \mathrm{gr}$ & $\begin{array}{l}\text { merah (baris 1) } \\
20 \text { gr (baris 2) }\end{array}$ & $\begin{array}{c}\text { Menuju wadah merah, } \\
\text { berat } 20 \text { gr }\end{array}$ & Berhasil \\
\hline & & $30 \mathrm{gr}$ & $\begin{array}{l}\text { merah (baris 1) } \\
30 \text { gr (baris 2) }\end{array}$ & $\begin{array}{c}\text { Menuju wadah merah, } \\
\text { berat } 30 \mathrm{gr}\end{array}$ & Berhasil \\
\hline & & $40 \mathrm{gr}$ & $\begin{array}{c}\text { merah (baris 1) } \\
40 \text { gr (baris 2) }\end{array}$ & $\begin{array}{c}\text { Menuju wadah merah, } \\
\text { berat } 40 \mathrm{gr}\end{array}$ & Berhasil \\
\hline & & $50 \mathrm{gr}$ & $\begin{array}{c}\text { merah (baris 1) } \\
50 \text { gr (baris 2) }\end{array}$ & $\begin{array}{c}\text { Menuju wadah merah, } \\
\text { berat } 50 \mathrm{gr}\end{array}$ & Berhasil \\
\hline
\end{tabular}


Tabel 3 Hasil Pengujian Keakuratan Gerak Lengan Robot dalam Menyeleksi warna biru dan variasi berat barang yang sesuai (diterima)

\begin{tabular}{|c|c|c|c|c|c|}
\hline \multirow[t]{2}{*}{ No. } & \multicolumn{2}{|c|}{ Kotak } & \multirow[t]{2}{*}{ Tampilan LCD } & \multirow{2}{*}{$\begin{array}{c}\text { Pergerakan lengan } \\
\text { robot }\end{array}$} & \multirow[t]{2}{*}{ Kesimpulan } \\
\hline & Warna & Berat & & & \\
\hline \multirow[t]{5}{*}{1} & \multirow[t]{5}{*}{ Biru } & $10 \mathrm{gr}$ & $\begin{array}{c}\text { biru (baris 1) } \\
10 \text { gr (baris 2) }\end{array}$ & $\begin{array}{c}\text { Menuju wadah biru, } \\
\text { berat } 10 \mathrm{gr}\end{array}$ & Berhasil \\
\hline & & $20 \mathrm{gr}$ & $\begin{array}{l}\text { biru (baris 1) } \\
20 \text { gr (baris 2) }\end{array}$ & $\begin{array}{c}\text { Menuju wadah biru, } \\
\text { berat } 20 \mathrm{gr}\end{array}$ & Berhasil \\
\hline & & $30 \mathrm{gr}$ & $\begin{array}{l}\text { biru (baris 1) } \\
30 \text { gr (baris 2) }\end{array}$ & $\begin{array}{l}\text { Menuju wadah biru, } \\
\text { berat } 30 \mathrm{gr}\end{array}$ & Berhasil \\
\hline & & $40 \mathrm{gr}$ & $\begin{array}{l}\text { biru (baris 1) } \\
40 \text { gr (baris 2) }\end{array}$ & $\begin{array}{l}\text { Menuju wadah biru, } \\
\text { berat } 40 \mathrm{gr}\end{array}$ & Berhasil \\
\hline & & $50 \mathrm{gr}$ & $\begin{array}{l}\text { biru (baris 1) } \\
50 \text { gr (baris 2) }\end{array}$ & $\begin{array}{l}\text { Menuju wadah biru, } \\
\text { berat } 50 \mathrm{gr}\end{array}$ & Berhasil \\
\hline
\end{tabular}

Tabel 4 Hasil Pengujian Keakuratan Gerak Lengan Robot dalam Menyeleksi warna hijau dan variasi berat barang barang yang sesuai (diterima)

\begin{tabular}{|c|c|c|c|c|c|}
\hline \multirow[t]{2}{*}{ No. } & \multicolumn{2}{|c|}{ Kotak } & \multirow[t]{2}{*}{ Tampilan LCD } & \multirow{2}{*}{$\begin{array}{c}\text { Pergerakan lengan } \\
\text { robot }\end{array}$} & \multirow[t]{2}{*}{ Kesimpulan } \\
\hline & Warna & Berat & & & \\
\hline \multirow[t]{5}{*}{1} & \multirow[t]{5}{*}{ Hijau } & $10 \mathrm{gr}$ & $\begin{array}{l}\text { hijau (baris 1) } \\
10 \text { gr (baris 2) }\end{array}$ & $\begin{array}{l}\text { Menuju wadah hijau, } \\
\text { berat } 10 \text { gr }\end{array}$ & Berhasil \\
\hline & & $20 \mathrm{gr}$ & $\begin{array}{l}\text { hijau (baris 1) } \\
20 \text { gr (baris 2) }\end{array}$ & $\begin{array}{c}\text { Menuju wadah hijau, } \\
\text { berat } 20 \mathrm{gr}\end{array}$ & Berhasil \\
\hline & & $30 \mathrm{gr}$ & $\begin{array}{l}\text { hijau (baris 1) } \\
30 \text { gr (baris 2) }\end{array}$ & $\begin{array}{l}\text { Menuju wadah hijau, } \\
\text { berat } 30 \mathrm{gr}\end{array}$ & Berhasil \\
\hline & & $40 \mathrm{gr}$ & $\begin{array}{l}\text { hijau (baris 1) } \\
40 \text { gr (baris 2) }\end{array}$ & $\begin{array}{c}\text { Menuju wadah hijau, } \\
\text { berat } 40 \mathrm{gr}\end{array}$ & Berhasil \\
\hline & & $50 \mathrm{gr}$ & $\begin{array}{l}\text { hijau (baris 1) } \\
50 \text { gr (baris 2) }\end{array}$ & $\begin{array}{l}\text { Menuju wadah hijau, } \\
\text { berat } 50 \mathrm{gr}\end{array}$ & Berhasil \\
\hline
\end{tabular}

Tabel 5 Hasil Pengujian Keakuratan Gerak Lengan Robot dalam Menyeleksi warna putih dan variasi berat barang barang yang sesuai (diterima)

\begin{tabular}{|c|c|c|c|c|c|}
\hline \multirow[t]{2}{*}{ No. } & \multicolumn{2}{|c|}{ Kotak } & \multirow[t]{2}{*}{ Tampilan LCD } & \multirow{2}{*}{$\begin{array}{c}\begin{array}{c}\text { Pergerakan lengan } \\
\text { robot }\end{array} \\
\text { pobot }\end{array}$} & \multirow[t]{2}{*}{ Kesimpular } \\
\hline & Warna & Berat & & & \\
\hline \multirow[t]{5}{*}{1} & \multirow[t]{5}{*}{ Putih } & $10 \mathrm{gr}$ & $\begin{array}{l}\text { putih (baris 1) } \\
10 \text { gr (baris 2) }\end{array}$ & $\begin{array}{c}\text { Menuju wadah putih, } \\
\text { berat } 10 \mathrm{gr}\end{array}$ & Berhasil \\
\hline & & $20 \mathrm{gr}$ & $\begin{array}{l}\text { putih (baris 1) } \\
20 \text { gr (baris 2) }\end{array}$ & $\begin{array}{c}\text { Menuju wadah putih, } \\
\text { berat } 20 \mathrm{gr}\end{array}$ & Berhasil \\
\hline & & $30 \mathrm{gr}$ & $\begin{array}{l}\text { putih (baris 1) } \\
30 \text { gr (baris 2) }\end{array}$ & $\begin{array}{c}\text { Menuju wadah putih, } \\
\text { berat } 30 \mathrm{gr}\end{array}$ & Berhasil \\
\hline & & $40 \mathrm{gr}$ & $\begin{array}{l}\text { putih (baris 1) } \\
40 \text { gr (baris 2) }\end{array}$ & $\begin{array}{c}\text { Menuju wadah putih, } \\
\text { berat } 40 \mathrm{gr}\end{array}$ & Berhasil \\
\hline & & $50 \mathrm{gr}$ & $\begin{array}{l}\text { putih (baris 1) } \\
50 \text { gr (baris 2) }\end{array}$ & $\begin{array}{c}\text { Menuju wadah putih, } \\
\text { berat } 50 \mathrm{gr}\end{array}$ & Berhasil \\
\hline
\end{tabular}


Keterangan :

Pada Tabel 2, Tabel 3, Tabel 4, Tabel 5. Pengujian yang dilakukan hanya kepada warna yang sesuai atau warna yang dterima oleh sistem secara program (merah, biru, hijau dan putih) begitu jg berat yang diuji coba merupakan berat yang sesuai oleh sistem (10 gr, 20 gr, 30 gr, 40 gr, dan 50 gr). Sehingga dapat dilihat bahwa sistem lengan robot yang diimplementasikan sebagai penyeleksi warna dan berat barang yang sudah diintegrasikan dengan sensor warna dan berat bekerja dengan akurat tanpa ada kesalahan dalam melakukan kerjanya.

Tabel 6 Hasil Pengujian Keakuratan Gerak Lengan Robot dalam Menyeleksi warna reject dan variasi berat barang yang tidak sesuai

\begin{tabular}{|c|c|c|c|c|c|}
\hline \multirow[t]{2}{*}{ No. } & \multicolumn{2}{|c|}{ Kotak } & \multirow[t]{2}{*}{ Tampilan LCD } & \multirow{2}{*}{$\begin{array}{c}\text { Pergerakan lengan } \\
\text { robot }\end{array}$} & \multirow[t]{2}{*}{ Kesimpulan } \\
\hline & Warna & Berat & & & \\
\hline \multirow[t]{5}{*}{1} & \multirow[t]{5}{*}{ Hitam } & $10 \mathrm{gr}$ & $\begin{array}{l}\text { hitam (baris 1) } \\
10 \text { gr (baris 2) }\end{array}$ & $\begin{array}{c}\text { Menuju wadah } \\
\text { reject }\end{array}$ & Berhasil \\
\hline & & $20 \mathrm{gr}$ & $\begin{array}{l}\text { hitam (baris 1) } \\
20 \text { gr (baris 2) }\end{array}$ & $\begin{array}{c}\text { Menuju wadah } \\
\text { reject }\end{array}$ & Berhasil \\
\hline & & $30 \mathrm{gr}$ & $\begin{array}{l}\text { hitam (baris 1) } \\
30 \text { gr (baris 2) }\end{array}$ & $\begin{array}{c}\text { Menuju wadah } \\
\text { reject }\end{array}$ & Berhasil \\
\hline & & $40 \mathrm{gr}$ & $\begin{array}{l}\text { hitam (baris 1) } \\
40 \text { gr (baris 2) }\end{array}$ & $\begin{array}{l}\text { Menuju wadah } \\
\text { reject }\end{array}$ & Berhasil \\
\hline & & $50 \mathrm{gr}$ & $\begin{array}{l}\text { hitam (baris 1) } \\
50 \text { gr (baris 2) }\end{array}$ & $\begin{array}{c}\text { Menuju wadah } \\
\text { reject }\end{array}$ & Berhasil \\
\hline \multirow[t]{5}{*}{2} & \multirow[t]{5}{*}{ Abu-abu } & $10 \mathrm{gr}$ & $\begin{array}{c}\text { abu-abu (baris 1) } \\
10 \text { gr (baris 2) }\end{array}$ & $\begin{array}{c}\text { Menuju wadah } \\
\text { reject }\end{array}$ & Berhasil \\
\hline & & $20 \mathrm{gr}$ & $\begin{array}{c}\text { abu-abu (baris 1) } \\
20 \text { gr (baris 2) }\end{array}$ & $\begin{array}{c}\text { Menuju wadah } \\
\text { reject }\end{array}$ & Berhasil \\
\hline & & $30 \mathrm{gr}$ & $\begin{array}{c}\text { abu-abu (baris 1) } \\
30 \text { gr (baris 2) }\end{array}$ & $\begin{array}{c}\text { Menuju wadah } \\
\text { reject }\end{array}$ & Berhasil \\
\hline & & $40 \mathrm{gr}$ & $\begin{array}{c}\text { abu-abu (baris 1) } \\
40 \text { gr (baris 2) }\end{array}$ & $\begin{array}{c}\text { Menuju wadah } \\
\text { reject }\end{array}$ & Berhasil \\
\hline & & $50 \mathrm{gr}$ & $\begin{array}{c}\text { abu-abu (baris 1) } \\
50 \text { gr (baris 2) }\end{array}$ & $\begin{array}{c}\text { Menuju wadah } \\
\text { reject }\end{array}$ & Berhasil \\
\hline \multirow[t]{3}{*}{3} & \multirow[t]{3}{*}{ Merah } & $15 \mathrm{gr}$ & $\begin{array}{l}\text { merah (baris 1) } \\
15 \text { gr (baris 2) }\end{array}$ & $\begin{array}{l}\text { Menuju wadah } \\
\text { reject }\end{array}$ & Berhasil \\
\hline & & $35 \mathrm{gr}$ & $\begin{array}{l}\text { merah (baris 1) } \\
35 \text { gr (baris 2) }\end{array}$ & $\begin{array}{l}\text { Menuju wadah } \\
\text { reject }\end{array}$ & Berhasil \\
\hline & & $70 \mathrm{gr}$ & $\begin{array}{c}\text { merah (baris 1) } \\
70 \text { gr (baris 2) }\end{array}$ & $\begin{array}{c}\text { Menuju wadah } \\
\text { reject }\end{array}$ & Berhasil \\
\hline \multirow[t]{3}{*}{4} & \multirow[t]{3}{*}{ Biru } & $15 \mathrm{gr}$ & $\begin{array}{l}\text { biru (baris 1) } \\
15 \text { gr (baris 2) }\end{array}$ & $\begin{array}{l}\text { Menuju wadah } \\
\text { reject }\end{array}$ & Berhasil \\
\hline & & $35 \mathrm{gr}$ & $\begin{array}{l}\text { biru (baris } 1 \text { ) } \\
35 \text { gr (baris 2) }\end{array}$ & $\begin{array}{c}\text { Menuju wadah } \\
\text { reject }\end{array}$ & Berhasil \\
\hline & & $70 \mathrm{gr}$ & $\begin{array}{l}\text { biru (baris } 1 \text { ) } \\
70 \text { gr (baris } 2 \text { ) }\end{array}$ & $\begin{array}{c}\text { Menuju wadah } \\
\text { reject }\end{array}$ & Berhasil \\
\hline \multirow[t]{2}{*}{5} & \multirow[t]{2}{*}{ Hijau } & $15 \mathrm{gr}$ & $\begin{array}{l}\text { hijau (baris 1) } \\
15 \text { gr (baris 2) }\end{array}$ & $\begin{array}{c}\text { Menuju wadah } \\
\text { reject }\end{array}$ & Berhasil \\
\hline & & $35 \mathrm{gr}$ & $\begin{array}{l}\text { hijau (baris } 1 \text { ) } \\
35 \text { gr (baris 2) }\end{array}$ & $\begin{array}{c}\text { Menuju wadah } \\
\text { reject }\end{array}$ & Berhasil \\
\hline
\end{tabular}


http://ejurnal.tunasbangsa.ac.id/index.php/jsakti

\begin{tabular}{|c|c|c|c|c|c|}
\hline No. & \multicolumn{2}{|c|}{ Kotak } & Tampilan LCD & $\begin{array}{c}\text { Pergerakan lengan } \\
\text { robot }\end{array}$ & Kesimpulan \\
\cline { 2 - 6 } & Warna & Berat & & herhasil \\
\cline { 2 - 6 } & & $70 \mathrm{gr}$ & $\begin{array}{c}\text { hijau (baris 1) } \\
70 \text { gr (baris 2) }\end{array}$ & $\begin{array}{c}\text { Menuju wadah } \\
\text { reject }\end{array}$ & Berhasil \\
\hline 6 & Putih & $15 \mathrm{gr}$ & $\begin{array}{c}\text { putih (baris 1) } \\
15 \text { gr (baris 2) }\end{array}$ & $\begin{array}{c}\text { Menuju wadah } \\
\text { reject }\end{array}$ & Berhasil \\
\cline { 2 - 7 } & & $35 \mathrm{gr}$ & $\begin{array}{c}\text { putih (baris 1) } \\
35 \text { gr (baris 2) }\end{array}$ & $\begin{array}{c}\text { Menuju wadah } \\
\text { reject }\end{array}$ & Berhasil \\
\cline { 2 - 7 } & $70 \mathrm{gr}$ & $\begin{array}{c}\text { putih (baris 1) } \\
70 \text { gr (baris 2) }\end{array}$ & $\begin{array}{c}\text { Menuju wadah } \\
\text { reject }\end{array}$ & Berhasil \\
\hline 7 & Hitam & $15 \mathrm{gr}$ & $\begin{array}{c}\text { hitam (baris 1) } \\
15 \text { gr (baris 2) }\end{array}$ & $\begin{array}{c}\text { Menuju wadah } \\
\text { reject }\end{array}$ & Berhasil \\
\hline 8 & Abu-abu & $70 \mathrm{gr}$ & $\begin{array}{c}\text { abu-abu (baris 1) } \\
70 \text { gr (baris 2) }\end{array}$ & $\begin{array}{c}\text { Menuju wadah } \\
\text { reject }\end{array}$ & . \\
\hline
\end{tabular}

Keterangan :

Pada Tabel 6, pengujian yang dilakukan terhadap warna yang tidak sesuai atau tidak diterima (hitam dan abu-abu) dan berat yang juga tidak sesuai (15 gr, 35 gr dan 70 gr). Dari pengujian dilakukan variasi pengujian warna yang tidak sesuai di gabung dengan berat yang tidak sesuai, warna sesuai dan berat yang tidak sesuai serta warna yang tidak sesuai dan berat yang tidak sesuai. Dari seluruh variasi pengujian pada Tabel 6 seluruh variasi membuat gerakan robot menuju kearah wadah reject, karena dari sistem telah ditentukan syarat yang mewajibkan kedua pembacaan sensor, baik warna maupun benar haris dengan warna dan berat yang sesuai yang telah ditentukan diprogram awal sistem. Dapat dilihat bahwa sistem lengan robot yang diimplementasikan sebagai penyeleksi warna dan berat barang yang sudah diintegrasikan dengan sensor warna dan berat bekerja dengan akurat tanpa ada kesalahan dalam melakukan kerjanya.

\section{SIMPULAN}

Hasil ujicoba sistem penyeleksian warna dan berat berat barang menggunakan pergerakan lengan robot yang dilakukan membuktikan bahwa sistem lengan robot mampu dan efektif dalam melakukan pergerakan yang akurat dalam memposisikan derajat geraknya dalam mengambil barang berwarna dalam berbagai variasi berat serta membawanya ke tempat/wadah yang sesuai dengan yang ditentukan. Hal ini telah menunjukkan bahwa semua perangkat yang ada pada sistem penyeleksian ini telah berhasil di integrasikan dan mencapai target yang diinginkan yaitu robot lengan yang dapat melakukan geraknya sebagai penyeleksi warna dan berat barang.

\section{DAFTAR PUSTAKA}

[1] The Robotic Institute, diakses pada Desember 2016, dari www.ri.cmu.edu.

[2] Endra Pitowarno, "Robotika Desain, Kontrol, dan Kecerdasan Buatan", Edisi I, Andi Offset, Yogyakarta, 2006. 
[3] Riyanto Sigit, "Robotika, Sensor dan Aktuator", Cetakan Pertama, Graha Ilmu, Yogyakarta, 2007.

[4] Hermawati, Euis W, Witarsa, Verdian, Yuniarti, and Caroline, "Prototipe Penyortir Barang Berdasarkan Warna, Bentuk Dan Tinggi Berbasis Programmable Logic Controller (PLC) Dengan Penggerak Sistem Pneumatic", Mikrotiga, Vol. 1, No. 2, Mei 2014.

[5] Datasheet Colour Sensor TCS3200, diakses dari e-book pada September 8, 2016, http://www.innovativeelectronics.com.

[6] Prastyono Eko Pambudi, Edhy Sutanta and Mujiman, “Identifikasi Daging Segar menggunakan Sensor Warna RGB TCS3200-DB”, Technoscientia, Vol. 6, No. 2, Februari 2014.

[7] Bambang Priyadi, “Aplikasi Sensor Warna Jenis TCS 230 sebagai Alat Penentu Komposisi Warna pada Cat Mobil”, Eltek, Vol. 10, No. 02, April 2012.

[8] Arief Cipta Indra Rukmana and Abdul Ro’uf, “Aplikasi Sensor Load Cell pada Purwarupa Sistem Sortir Barang", Ijeis, Vol. 4, No.1, pp.35-44, April 2014.

[9] Tarigan Pernantin, "Sistem Tertanam (Embedded System)", Cetakan Pertama, Graha Ilmu, Yogyakarta, 2011.

[10] Yao Li, "An Automatic Determination Method based on Color Sensor at The End Point of The Titration", Proc. Of Second International Conference on Mechanic Automation and Control Engineering", p.3836 - 3838, Nanjing, China, 15-17 July 2011.

[11] Datasheet Mikrokontroler AVR Atmega32, diakses dari e-book pada Desember 8, 2016, http://www.atmel.com. 